\title{
Duplik Sebagai Upaya Tergugat Konvensi/Penggugat Rekonvensi Dalam Mempertahankan Argumentasi Dalam Jawaban Atas Gugatan Penggugat Konvensi/Tergugat Rekovensi
}

\author{
Ery Agus Priyono \\ Fakultas Hukum, Universitas Diponegoro \\ Eap_fh_undip @ yahoo.com
}

A. Pendahuluan

Replik yaitu adalah jawaban penggugat dalam hal baik terulis maupun juga lisan terhadap jawaban tergugat atas gugatannya. Replik diajukan oleh penggugat untuk meneguhkan gugatannya tersebut, dengan cara mematahkan berbagai alasan dalam penolakan yang dikemukakan tergugat di dalam jawabannya. Replik adalah lanjutan dari suatu pemeriksaan dalam perkara perdata di dalam pengadilan negeri setelah tergugat mengajukan jawabannya. Replik ini berasal dari 2 kata yakni re (kembali) dan pliek (menjawab), jadi dapat kita simpulkan bahwa replik berarti kembali menjawab.

Duplik yaitu adalah jawaban tergugat terhadap suatu replik yang diajukan oleh penggugat. Sama juga halnya dengan replik, duplik ini juga bisa diajukan baik dalam bentuk tertulis maupun dalam bentuk lisan. Duplik ini diajukan oleh tergugat untuk meneguhkan jawabannya yang pada lazimnya berisi suatu penolakan terhadap suatu gugatan pihak penggugat.

B. Contoh Duplik

Semarang, 14 Agustus 2018

Kepada Yth.

\section{Ketua Majelis Hakim Pengadilan Agama Semarang}

Di

tempat

Assalamualaikum warahmatullaahi wabarakaatuh.

Dengan hormat,

Yang bertanda tangan di bawah ini:

, lahir di Surabaya tanggal 14 Agustus 1966, agama Islam, pendidikan D1, pekerjaan Ibu rumah tangga, 
bertempat tinggal di

Kota Semarang, sebagai Termohon

Konvensi/Penggugat Rekonvensi.

Majelis Hakim yang semoga senantiasa dirahmati Allah Subhanahu wa Ta'ala Saudara Pemohon Konvensi/Tergugat Rekonvensi atau kuasa hukumnya yang kami hormati

Bahwa setelah membaca dengan cermat dan memahami maksud dari Replik yang diajukan oleh Pemohon Konvensi/Tergugat Rekonvensi dengan ini Termohon Konvensi/Penggugat Rekonvensi hendak mengajukan tanggapan, sanggahan, sangkalan, bantahan, pendapat dan/atau Duplik atas Replik Pemohon Konvensi/Tergugat Rekonvensi, sebagai berikut:

\section{Dalam Konvensi :}

1. Bahwa segala dalil-dalil dan dasar hukum yang terurai dalam Jawaban Pemohon Konvensi/Tergugat Rekonvensi terhadap Permohonan Talak yang diajukan Pemohon Konvensi/Tergugat Rekonvensi yang telah disampaikan sebelumnya dalam Permohonan Talak, Perkara Perdata yang terdaftar di Kepaniteraan Pengadilan Agama Semarang No. 800/Pdt.G/2018/PA., mohon dianggap dan dinyatakan berlaku (mutatis mutandis) dalam Duplik Termohon Konvensi/Penggugat Rekonvensi, kecuali yang secara tegas diingkari oleh Termohon Konvensi/Penggugat Rekonvensi dalam Duplik ini ;

2. Bahwa dalam Repliknya pada dalil konvensi angka 1, Pemohon Konvensi/Tergugat Rekonvensi terkesan dengan jelas tidak memahami istilahistilah dalam Hukum Acara Perdata yang berlaku di Indonesia. Misalnya Pemohon Konvensi/Tergugat Rekonvensi menggunakan istilah Gugatan Pemohon Konvensi/Tergugat Rekonvensi yang semestinya Permohonan Talak dari Pemohon Konvensi/Tergugat Rekonvensi, hal lainnya Pemohon Konvensi/Tergugat Rekonvensi menyebut perkara no No. 800/Pdt.G/2018/PA sebagai Gugatan Perkara Perdata semestinya Permohonan Talak.

3. Bahwa pada Repliknya Permohon Konvensi/Tergugat $\quad$ Rekonvensi, menggunakan istilah yang tidak tepat sehingga maksudnya menjadi tidak jelas, gelap, samar samar serta membingungkan yang dalam hukum acara disebut "obscure libel" dan sebagai akibat hukumnya permohonan yang diajukan Pemohon Konvensi/Tergugat Rekonvensi dapat dinyatakan tidak bisa diterima (N.O)

4. Bahwa Termohon Konvensi/Penggugat Rekonvensi dengan ingin menjelaskan beberapa hal selaih yang tersebut di atas, sebagai berikut :

a. Pemohon Konvensi/Terggugat Rekonvensi selama menjalani kehidupan berumah tangga dengan Pemohon Konvensi/Tergugat Rekonvensi dalam rumah tangganya pasti ada kerikil kecil dan masalah, akan tetapi Termohon Konvensi/Penggugat Rekonvensi tidak pernah mengatakan "DJANCUK atau TAK TINGGAL MINGGAT”. Bahkan selama 27 tahun Termohon 
Konvensi/Penggugat Rekonvensi berumah tangga dengan Permohon Konvensi/Tetgugat Rekonvensi tidak pernah sekalipun meninggalkan rumah dan tidak pernah membiarkan anak-anak dan suami terlantar untuk memenuhi kehidupan hidup, membesarkan anak-anak, dan mendampingi Pemohon Konvensi/Tergugat Rekonvensi.

b. Berkaitan dengan foto PemohonKonvensi/Tergugat Rekonvensi memutar balikan fakta bahwa bukti kemesraan antara Pemohon Konvensi/Tergugat Rekonvensi dan Termohon Konvensi/Penggugat Rekonvensi adalah benar adanya. Kemesraan ini dibuktikan dengan foto tersebut diambil kami masih tinggal satu rumah.

c. Termohon Konvensi/Penggugat Rekonvensi menganggap Pemohon Konvensi/Tergugat Rekonvensi bersikap biasa saja tidak terlihat sedang memendam perasaan yang tidak enak terhadap termohon Konvensi/Penggugat Rekonvensi. Hal ini dibuktikan dengan anak-anak yang juga selalu menghabiskan waktu bersama Pemohon Konvensi/Tergugat Rekonvensi dan Pemohon Konvensi/Tergugat Rekonvensi selalu menjemput dan mengantar ketika anak kami yang pertama pulang ke Semarang.

d. Bagaimana berpura-pura kenyataannya seperti itu terjadi ribut-ribut kecil itu biasa tidak sampai ingin bercerai. Bagaimana mungkin seorang istri dan anak-anak mau kehilangan suaminya atau ayahnya. Jadi disini Termohon Konvensi/Penggugat Rekonvensi dan anak-anak menolak tegas perceraian ini.

e. Termohon Konvensi/Penggugat Rekonvensi sebagai tulang rusuk berperan ganda menjadi tulang punggung dalam keluarga hal ini dilakukan semata-mata untuk melangsungkan kehidupan rumah tangga antara Pemohon Konvensi/Tergugat Rekonvensi dan Termohon Konvensi/Penggugat Rekonvensi .

f. Karena Termohon Konvensi/Penggugat Rekonvensi emosi dengan ulah Pemohon Konvensi/Tergugat Rekonvensi setelah tahu adanya indikasi Pemohon Konvensi/Tergugat Rekonvensi memiliki Wanita Idaman Lain (WIL), Pemohon Konvensi/Tergugat Rekonvensi selalu berkata kasar, dan pulang pagi. Dengan adanya WIL Pemohon Konvensi/Tergugat Rekonvensi Konvensi berubah sikap menjadi tidak baik, tidak romantis ,yang menjadikan Termohon Konvensi/Penggugat Rekonvensi merasa dinomor 2 kan.

g. Tidak ada perselingkuhan antara Termohon Konvensi/Penggugat Rekonvensi dengan Laki-laki manapun karena bagi Termohon Konvensi/Penggugat Rekonvensi, Pemohon Konvensi/Tergugat Rekonvensi adalah laki-laki terbaik bagi Termohon Konvensi/Penggugat Rekonvensi dan bagi putra putrinya, dan sebagai bukti cinta di antara kami, Termohon Konvensi/Penggugat Rekonvensi telah dikaruniai 4 buah hati, sebagai buah perkawinan di mana bagi Pemohon Konvensi/Tergugat Rekonvensi kami adalah keluarga yang utuh dan bahagia. h. Terkait dengan tuduhan bahwa Termohon Konvensi/Penggugat Rekonvensi,mengalami gangguan kejiwaanadalah tidak benar sama sekali dan 
terkesan mencari-cari kesalahan. Hal ini dapat dibuktikan hingga saat ini tidak ada rekam medis/surat keterangan dari Dokter Jiwa atau Rumah Sakit jiwa yang menyatakan bahwa Termohon Konvensi/Penggugat Rekonvensi sedang dalam gangguan jiwa. Alhamdulillah sejauh ini saya Termohon Konvensi/Penggugat Rekonvensi sanggup mengerjakan semua pekerjaan dan mendidik anak-anak saya dengan baik.Tidak ada tanda-tanda kejiwaan bahwa saya sedang labil.Mengingat Termohon Konvensi/Penggugat Rekonvensi sendiri harus tegar untuk mendampingi dan membimbing anak-anak untuk tetap melanjutkan cita-citanya.

\section{Dalam Rekonvensi :}

1. Bahwa segala dalil-dalil dan dasar hukum yang terurai dalam Jawaban Termohon Konvensi/Penggugat Rekonvensi terhadap Permohonan Talak yang diajukan Pemohon Konvensi/Tergugat Rekonvensi yang telah disampaikan sebelumnya dalam Permohonan Talak, dalam Perkara Perdata yang terdaftar di Kepaniteraan Pengadilan Agama Semarang No. 800/Pdt.G/2018/PA., mohon dianggap dan dinyatakan berlaku (mutatis mutandis) dalam Duplik Termohon Konvensi/Penggugat Rekonvensi, kecuali yang secara tegas diingkari oleh Termohon Konvensi/Penggugat Rekonvensi dalam Duplik ini, baik di dalam jawaban Konvensi maupun jawaban Rekonvensi dari Duplik ini.

2. Bahwa di dalam sebuah Replik secara normatif berisi Fondamentum Petendi dan Petitum. Fondamentum Petendi isinya uraian peristiwa dan dasar hukum permohonan/gugatan yang harus memenuhi syarat jelas dan lengkap. Petitum isinya apa yang dituntut syaratnya terang dan pasti.

3. Bahwa dalam Replik yang diajukan oleh Permohon Konvensi/Tergugat Rekonvensi, dalam Konvensi tampak nyata dan tidak samar lagi dalam Fondamentum Petendinya (angka 1 samapai 8) tercantum uraian fakta akan tetapi tanpa mencantumkan dasar hukum, sehingga sudah semestinya ditolak oleh majelis hakim yang terhormat. Karena tidak memenuhi syarat sebuah Fondamentum Petendi.

4. Bahwa dalam Rekonvensi, Permohon Konvensi/Tergugat Rekonvensi dalam Repliknya tidak mencantumkan sama sekali uraian fakta maupun dasar hukum, tetapi dalam Petitumnya muncul tuntutan dalam rekonvensi.

5. Bahwa dalam Petitumnya tiba tiba mengajukan tuntutan Rekonpensi tanpa ada uraian fakta dan dasar hukum dalam rekonpensi pada Replik yang diajukan oleh Permohon Konvensi/Tergugat Rekonvensi.

6. Bahwa pada Replik Permohon Konvensi/Tergugat Rekonvensi, membuat dalil-dalil yang tidak jelas, gelap, dan samar samar serta membingungkan yang dalam hukum acara disebut "obscure libel" dan sebagai akibat hukumnya permohonan yang diajukan Permohon Konvensi/Tergugat Rekonvensi dapat dinyatakan tidak bisa diterima (N.O) 
7. Bahwa Termohon Konvensi/Penggugat Rekonvensi tetap dengan dalil-dalil dalam hal-hal sebagai berikut :

a. Uang Mut'ah sebesar Rp 15.000.000/per bulan, karena termohon telah berumah tangga dengan melayani pemohon selama 27 tahun. Jadi, mut'ah yang harus dibayar oleh mantan suami sebesar Rp 15.000.000 x 12 bulan $=\mathbf{R p}$ 180.000.000 x 27 tahun, maka hasil yang diperoleh dari perhitungan ialah $\mathbf{R p}$ 4.860.000.000,00.

b. Nafkah iddah, yang dimana nafkah yang harus diberikan oleh mantan suami kepada mantan istri jika perceraian terjadi karena talak. Rp 75.000.000 selama 3 bulan, maka diperoleh hasil sejumlah Rp 225.000.000.

c. Nafkah 2 anak yang masih dalam tanggungan ialah,

a). 17 tahun.

Nominal Rp 10.000.000 x 12 bulan $\times 8$ tahun $=$ Total akhir Rp 960.000.000.

b). , 15 tahun.

Nominal Rp 10.000.000 x 12 bulan x 9 tahun $=$ Total akhir $\mathbf{R p}$ 1.080.000.000.

d. Biaya Sekolah.

$>$, berencana melanjutkan pendidikan di

Fakultas Kedokteran Swasta. Dengan rincian biaya sebagai berikut:

- Biaya pendaftaran $\quad$ Rp $\mathbf{3 0 0 . 0 0 0 . 0 0}$

- Uang gedung $\quad$ Rp 350.000 .000 .00

- $\quad$ Sks Rp 39.000.000 x 12 semester $=\quad$ Rp 468.000 .000 .00

- Praktek $\underline{\mathbf{R p ~} 450.000 .000 .00}$

Total

Rp 1.268.300.000,00

- Melanjutkan pendidikan di SMK N 7 Semarang.

- SPP Rp 200.000 x 12 bulan $\times 4$ tahun =

- Uang pengenalan industri

Rp 9.600.000,00

- Bali Study Tour

- Ketahanan sekolah

- Seragam

Rp 500.000,00

Rp 2.500.000,00

Total

Rp $\quad 500.000,00$

$\underline{\operatorname{Rp} 3.000 .000,00}$

Rp 16.100.000,00

$>$ Melanjutkan pendidikan di Perguruan Tinggi PLN

- Uang gedung

Rp 35.390.000,00

- BP Asuransi

Rp $\quad 3.020 .000,00$

- SKS per 2 semester Rp 42.310 .000 x 4 tahun $\underline{\text { Rp169.240.000,00 }}$

Total

Rp207.650.000,00

8. Bahwa Nafkah anak tidak mungkin di kesampingkan karena anak-anak mempunyai hak untuk tetap hidup dengan baik dan meneruskan cita-citanya demi masa depannya. Jadi disini point $d$ dan point e bertentangan dengan pasal 45 ayat 1 dan 2 . Undang-undang no.1 tahun 1974 tentang Perkawinan, yang menyatakan 
bahwa kedua orang tua wajib memelihara dan mendidik anak-anak mereka sebaikbaiknya sampai anak-anak nenikah atau dapat berdiri sendiri, kewajiban tersebut masa berlakunya terus meskipun perkawinan antara kuda orang tuanya putus.

9. Pada dasarnya, saya, Termohon Konvensi/Penggugat Rekonvensi masih ingin tetap hidup rukun dengan Pemohon Konvensi/Tergugat Rekonvensi karena Termohon Konvensi/Penggugat Rekonvensi masih mencintai Pemohon Konvensi/Tergugat Rekonvensi dan demi keberlangsungan masa depan anakanak, yang merupakan buah cinta kasih antara Termohon Konvensi/Penggugat Rekonvensi dengan Pemohon Konvensi/Tergugat Rekonvensi .

10. Bahwa Termohon Konvensi/Penggugat Rekonvensi tidak mengadaada bahwa surat yang dituliskan dengan kata-kata wasiat oleh Pemohon itu benar adanya, yang ditulis didepan kedua kakak Pemohon nomor 1 bersama istrinya dan 4 , dan dititipkan kepada kakak Pemohon nomor 1 bersma istrinya diberikan kepada anak Pemohon yang nomor 1 dan nomor 4. Jadi disini Termohon tidak mengadaada dan sudah selayaknya Rumah Tanah yang berada di

menjadi milik keempat anak Pemohon dan Termohon. Karena dirumah ini lah anak-anak tinggal sejak kecil bertahun-tahun di rumah itu untuk berlindung agar tetap hidup dan bersekolah demi masa depannya.

11. Untuk menanggapi tentang keserakahan atau ingin menguasai harta disini sesuai AL-QURAN Surat AN-NISA ayat 20-21 yang artinya berbunyi:

Ayat 20 :

"Jika kamu ingin mengganti istrimu yang lain , sedang kamu telah memberikan kepadanya harta yang banyak maka jangan lah kamu mengambilnya sedikitpun darinya. Apakah kamu akan mengambilnya kembali dengan tuduhan yang dusta. Dan menangggung dosa yang nyata."

Ayat 21:

"Dan bagaimana kamu akan mengambilnya kembali, padahal kamu telah bergaul satu sama lain sebagai suami istri dan mereka istrimu telah mengambil perjanjian yang kuat (Ikatan Pernikahan) dari kamu.

Berdasarkan hal - hal yang telah terurai di atas, mohon dengan hormat sudilah kiranya Majelis Hakim untuk memeriksa dan memutus perkara ini dengan memberi putusan sebagai berikut:

\section{DALAM KONVENSI}

1. Menolak Permohonan Pemohon Konvensi untuk seluruhnya

2. Menghukum Pemohon Konvensi untuk membayar biaya perkara yang timbul dalam perkara ini, 


\section{DALAM REKONVENSI}

1. Menyatakan Permohonan dari Pemohon konvensi/Tergugat Rekonvensi tidak dapat diterima (NO)

2. Menghukum Pemohon Konvensi/Tergugat Rekonvensi untuk membayar :

a. Uang Mut'ah sebesar Rp 4.860.000.000,00.

b. Nafkah iddah sebesar Rp 225.000.000.

c. Nafkah 2 anak yang masih dalam tanggungan sebesar RP. 2.040.000,00,

d. Biaya Sekolah/kuliah :

$>$ Thazya Syalsyah Dhila Poetri, sebesar Rp 1.268.300.000,00

$>$ Muhammad Irga Angkasa Poetra, sebesar Rp. 207.650.000,00

3. Menghukum Pemohon Konvensi/Tergugat Rekonvensi untuk membayar sernua biaya yang timbul dari perkara ini.

Atau : Jika Pengadilan Agama Semarang berpendapat lain mohon putusan yang seadil adilnya berdasarkan Ketuhanan yang Maha Esa dan

sesuai dengan prinsip dalam sebuah Peradilan Islam;

Hormat kami, TermohonKonvensi/Penggugat Rekonvensi 